\author{
Markus Eberharter \\ Instytut Lingwistyki Stosowanej UW \\ markus.eberharter@uw.edu.pl
}

\title{
WIKTOR HR. BAWOROWSKI. BIBLIOFIL I TŁUMACZ
}

DOI: http://dx.doi.org/10.12775/RP.2017.006

\begin{abstract}
Zarys treści: Wiktor hr. Baworowski (1826-1894) znany jest jako galicyjski bibliofil i założyciel biblioteki swojego imienia. Niniejszy artykuł przypomina jego sylwetkę jako tłumacza, autora przekładów ważnych XIX-wiecznych pisarzy, takich jak Christoph Martin Wieland, Lord Byron lub Victor Hugo. Po krótkim zarysie biografii oraz socjalizacji językowej i literackiej Baworowskiego artykuł szczegółowo omawia niepublikowany dotychczas tekst Baworowskiego O tłumaczeniach, obszerną refleksję na temat istoty i historii przekładu literackiego w Polsce. Ostatnia część tekstu przedstawia recepcję przekładów Baworowskiego przez ówczesną krytykę literacką oraz próbuje dać odpowiedź na pytanie, na ile jego praca przekładowa oraz bibliofilsko-kolekcjonerska wyrosły ze zbieżnych intencji.
\end{abstract}

Słowa kluczowe: Wiktor Baworowski, przekład literacki XIX wieku, historia przekładu (Polska), tłumacz (biografia)

D ziś Wiktor Baworowski jest znany najbardziej jako dziewiętnastowieczny kolekcjoner książek, starodruków i rękopisów, a także fundator biblioteki noszącej jego imię - obok Biblioteki Zakładu Narodowego im. Ossolińskich oraz Biblioteki Uniwersyteckiej jednego z największych i najcenniejszych księgozbiorów we Lwowie przed drugą wojną światową ${ }^{1}$. Był on jednak również cenionym tłumaczem, który przekładał na język polski kluczowych autorów XIX wieku, takich jak Lord Byron, Friedrich Schiller lub Victor Hugo.

${ }^{1}$ Odnośnie do dziejów i charakterystyki księgozbioru Baworowskiego zob.: Chamera-Nowak 2008. Ponieważ jest to osobny temat, ograniczam się w tym miejscu do wskazania na ten artykuł, który daje nie tylko dobry ogląd tego zagadnienia, lecz wymienia także najważniejszą literaturę przedmiotową. 
Zwłaszcza jego przekłady Byrona, Childe Harolda oraz Don Juana, przyniosły mu duże uznanie wśród krytyków, nie tylko w rodzimej Galicji. Mimo to Baworowski jako tłumacz jest dziś prawie zapomniany, próżno szukać go np. w zarysie dziejów polskiego przekładu literackiego Wacława Sadkowskiego (2013), również w antologii o sztuce przekładu redagowanej przez Edwarda Balcerzana i Ewę Rajewską (2007) jego nazwisko nie występuje.

Celem mojego tekstu jest zatem przypomnienie sylwetki Baworowskiego jako tłumacza oraz opisanie drogi, która przywiodła go do tego zajęcia. Chciałbym także poszukać odpowiedzi na pytanie, czy i na ile jego aktywność jako bibliofila-kolekcjonera oraz jego praca przekładowa wynikały ze zbieżnych intencji, tzn. na ile Baworowski mógł być przekonany, że swoją działalnością na tych polach przyczynia się do wzbogacenia i rozwoju kultury polskiej. Kluczowym punktem mojego artykułu będzie charakterystyka jego koncepcji przekładu literackiego na podstawie dość obszernego, nigdy nieopublikowanego tekstu, w którym zarysował zarówno historię przekładu literackiego w Polsce od XVI wieku do czasów mu współczesnych, jak i starał się zdefiniować najważniejsze cechy udanego tłumaczenia. O ile mi wiadomo, tekst ten do tej pory nie wszedł do dyskusji nad przekładem w ujęciu historycznym w Polsce. W końcu chciałbym zbadać, jak Baworowski i jego praca przekładowa byli postrzegani przez współczesnych.

Wiktor hrabia Baworowski ${ }^{2}$ urodził się w 1826 roku - nie jest znana dokładna data - w Kołtowie, położonym pomiędzy Złoczowem a Brodami, $75 \mathrm{~km}$ na wschód od Lwowa. Po śmierci rodziców, w 1837 oraz 1841 roku, trafił pod opiekę wuja Michała hr. Starzeńskiego, który wysłał go do Lwowa, gdzie otrzymał dalsze wychowanie. Ukończywszy studia, w 1848 roku podjął na życzenie wuja pracę w Namiestnictwie Galicyjskim, z czego zrezygnował kilka lat później. Coraz bardziej poświęcał się pracom literackim oraz tłumaczeniom, publikując, począwszy od roku 1853, swoje przekłady we lwowskim „Dzienniku Literackim”. W tym samym roku został także wydany $\mathrm{w}$ formie książkowej pierwszy jego przekład - poemat romantyczny Christopha Martina Wielanda Oberon. W kolejnych latach Baworowski intensywnie

2 Najważniejszym źródłem do biografii Baworowskiego jest jego autobiograficzna notatka (por. Baworowski b. r./a), która znajduje się w formie rękopisu w Bibliotece Jagiellońskiej. O ile nie zaznaczono inaczej, opieram się przy podawaniu faktów o jego życiu poza tym na obszernych portretach Baworowskiego pióra Józefa Ignacego Kraszewskiego (1877) oraz na haśle w Polskim Słowniku Biograficznym („Baworowski hr. Wiktor” 1989), w których - jak pokazuje analiza porównawcza - także obficie korzystano z wymienionej notatki autobiograficznej. Pełną bibliografię literatury składającą się z kilkunastu artykułów i opracowań na temat osoby i twórczości Baworowskiego podaje Nowy Korbut - por. „Baworowski Wiktor (1826-1894)” 1968: 138-139. 
zajmował się zarządzaniem swoimi dobrami, które odziedziczył w okolicach Tarnopola, sam mieszkając ok. $10 \mathrm{~km}$ na południe, w Myszkowicach. Majątek ziemski, którym dysponował, był „olbrzymi”, dzięki czemu Baworowski uchodził za człowieka bardzo bogatego - Henryk Barycz mówi o nim np. „pan wielkiej fortuny” (Barycz 1963: 72-73), autor zaś jego nekrologu w petersburskim polskojęzycznym tygodniku „Kraj” określa go mianem „niezmiernie bogatego" („Wiktor hr. Baworowski” 1894, 16). Fakt ten miał oczywiście duże znaczenie dla jego pasji kolekcjonerskiej, która $\mathrm{z}$ reguły wymaga znacznych nakładów finansowych; w pewnym sensie oddziaływał też na jego pracę literacką i przekładową, Baworowski nie musiał się bowiem zmagać np. z problemami finansowymi przy publikacji czy też liczyć na ewentualne zyski ze sprzedaży swoich przekładów. Co więcej, mógł je przeznaczyć na cele społeczne. Tak postąpił w wypadku przekładu Don Juana Byrona, z którego dochód przekazał rannym. Jak można wnioskować z roku wydania książki - 1863, chodziło o rannych w powstaniu styczniowym (por. Byron 1863, str. tytułowa). Dochód z kolejnego przekładu Don Juana z 1879 roku ofiarował zaś „Towarzystwu bratniej pomocy słuchaczów wszechnicy lwowskiej” (por. Byron 1879: str. tytułowa). Biografowie Baworowskiego nie przemilczają jednak także faktu, że życie w samotności na wsi, przerywane jedynie nielicznymi podróżami do Włoch lub do Francji, doprowadziło go do rozgoryczenia i do zdziwaczenia. 3 grudnia 1894 roku we Lwowie Baworowski odebrał sobie życie. Czy przyczyną samobójstwa była samotność i poczucie braku uznania dla twórczości oraz towarzysząca im melancholia, jak przypuszcza krakowski publicysta Ludwik Dębicki (por. 1906: 233-234) - nie wiadomo. Niektóre źródła podają też, że Baworowski miał coraz większe problemy ze wzrokiem i że groziła mu ślepota. Został pochowany przy tłumnym udziale swoich współobywateli w Baworowie, niedaleko swojego miejsca zamieszkania.

Chciałbym przyjrzeć się bliżej procesowi socjalizacji językowej i literackiej, w trakcie których Baworowski nabywał umiejętności niezbędnych dla tłumacza. Była to droga co najmniej nierówna, był on bowiem, co nie stanowiło wówczas wyjątku, wychowywany nie po polsku, lecz w językach obcych, mimo patriotycznej atmosfery panującej $w$ domu rodzinnym ${ }^{3}$. Kraszewski pisze:

Przyszyły tłumacz Byrona słyszał dokoła mowy niemal wszystkich narodów, prócz rodzinnej. W domu i w większej części towarzystw znaczniejszych mówiono po-

${ }^{3}$ Zob. dokładniej do tego aspektu: Dybiec 2004: 18-21, w szczególności 20, gdzie m.in. pisze, że wychowanie w obcym języku (najczęściej francuskim) było w XIX wieku dość powszechnym zjawiskiem, zarówno w szlacheckich, jak i w zamożniejszych i kulturalnych domach. 
wszechnie po francuzku ${ }^{4}$ niekiedy po angielsku; w stosunkach ze wszystkiemi władzami krajowemi używany był język niemiecki, z ludem mówiono po rusińsku [...]. Wiemy to ust samego hr. Wiktora, iż początkowo tak zwichnięty tem wychowaniem cudzoziemskiem, iż inaczej myśleć nie mógł jak po francuzku, lub po niemiecku, i najmniejszego listu nie umiał napisać po polsku (Kraszewski 1877: 226).

Również wychowanie, które otrzymał od wuja, przeniósłszy się po śmierci rodziców do Lwowa, nie sprzyjało jego rozwojowi językowo-literackiemu w języku polskim. Wuj nie lubił bowiem zwłaszcza nowszej literatury polskiej, a wychowanie we Lwowie nadzorował pedagog o nazwisku Jurgass lub Jürgass, z pochodzenia Prusak, który dbał o to, żeby wychowanek uczył się „wszystkiego prócz języka, historiji i literatury polskiej” („Baworowski hr. Wiktor" 1989: 369). Mimo to Baworowski podczas lwowskich lat gimnazjalnych oraz studiów zaczął we własnym zakresie, ponoć po kryjomu oraz „na przekór wujowi” („Baworowski hr. Wiktor” 1989: 369), czytać coraz intensywniej autorów polskich, niemieckich i francuskich, rozwijając tym samym swoje umiejętności zwłaszcza w języku polskim. W tym czasie powstały także jego pierwsze prace literackie oraz drobne tłumaczenia z języków francuskiego i niemieckiego.

Duże znaczenie dla rozwoju literackiego i dla fascynacji Baworowskiego kulturą i tradycją polską, a być może także dla jego decyzji, by trudzić się tłumaczeniem, miały kontakty osobiste. Sam wspominał m.in. o swoim nauczycielu z dzieciństwa, jednym z tłumaczy paryskich wykładów Adama Mickiewicza o literaturze słowiańskiej na język niemiecki, Kazimierzu Kunaszowskim, któremu zawdzięcza „poczucie jednak polskie i zamiłowanie do rzeczy narodowych” (Baworowski b.r./a) i od którego mógł „nabrać poszanowania i miłości dla rodowitej mowy" (Kraszewski 1877: 226). Najważniejszy jednak był kontakt z Janem Nepomucenem Kamińskim, którego poznał w 1847 roku i który został jego nauczycielem języka i literatury polskiej, o czym Baworowski wiele lat później sam wspomina (zob. Baworowski 1888: 153). Kamiński był nie tylko długoletnim dyrektorem teatru polskiego we Lwowie, lecz także pisarzem, krytykiem i w końcu tłumaczem, przede wszystkim sztuk teatralnych z języka niemieckiego. Po Kunaszowskim Kamiński był zatem już drugim tłumaczem odgrywającym ważną rolę w literacko-językowym rozwoju Baworowskiego i być może to właśnie on zainspirował go do pracy przekładowej. Wiemy na pewno, gdyż Baworowski pisze o tym

\footnotetext{
${ }^{4}$ Przy wszystkich cytatach zachowano w tym artykule oryginalną pisownię tekstu źródłowego.
} 
w swojej notce autobiograficznej, że Kamiński doradził mu tłumaczenie Oberona Wielanda. Mieli poza tym wspólną wizję znaczenia, jakie ich praca literacka może mieć w Polsce porozbiorowej. Biografka Kamińskiego, Barbara Lasocka, pisze, że „poprzez teatr utrzymał [Kamiński] język polski, narodową świadomość, ojczyste tradycje" (Lasocka 1972: 102). Baworowski miał dość podobny pogląd na rolę przekładu literackiego, o czym jeszcze będzie jeszcze mowa. Również w późniejszych latach, kiedy w galicyjskim środowisku literackim był już uznanym tłumaczem, utrzymywał rozmaite kontakty $\mathrm{z}$ ważnymi postaciami życia literackiego, które prosił o ocenę swoich przekładów, a czasem też o korektę manuskryptów oraz o rady, np. w sprawie dalszych przedsięwzięć. Korespondował w związku z tym np. z Kornelem Ujejskim i Henrykiem Sienkiewiczem (por. Nadolski 1934; Hahn 1946). Ostatniego pytał, jakich autorów lub jakie dzieła warto jego zdaniem przekładać na język polski, po czym Sienkiewicz w liście do Baworowskiego z 20 marca 1890 roku zarysował szeroki krąg, począwszy od literatury angielskiej, rzucając - „nie [...] z określonym zamiarem" - nazwiska Percy’ego Bysshe Shelleya, Alfreda Tennysona oraz Williama Shakespeara, wyliczając dalej literaturę klasyczną (Iliadę oraz tragedie i poezję, gdyż istniejące polskie tłumaczenia były często złe) oraz hinduską, z której wymienił Mahabharaty i Ramajany, pisząc: „Jest to morze całe roboty. [...] Ja bym rad, żebyś Szanowny Pan przełożył wszystko, co nie było tłumaczone, plus to, co było źle tłumaczone" (Sienkiewicz 1951: 19). O ocenę i radę Baworowski prosił także Mickiewicza, którego odwiedził na początku 1853 roku w Paryżu. Otrzymał pochwałę za przekład Oberona, Mickiewicz przyznał natomiast, że nie lubi Wielanda i polecił mu raczej zająć się Shakespearem, Dantem, Odysseją, Ariostem, Goethem lub Byronem (por. Baworowski 1856: 42/334).

W tym kontekście wymienia Mickiewicz poemat Wędrówki Childe Harolda (Childe Harold's Pilgrimage), nietłumaczony wtedy jeszcze na polski. Czy Baworowski bezpośrednio skorzystał z tej rady - trudno jednoznacznie stwierdzić, nie jest to natomiast w kontekście powyżej rozmowy wykluczone. Faktem bowiem jest, że już trzy lata później opublikował ${ }^{5}$ pierwsze przekłady właśnie z Pielgrzymki Czajlda Harolda - pierwsze dwie pieśni, które ukazały się najpierw w czasopismach, a w 1857 roku także w drukarni lwowskiej Ossolineum jako osobna książka. Trzecią pieśń ogłosił dopiero w 1868 roku, przekład czwartej i ostatniej zaś pozostał tylko w rękopisie. Z Byrona Bawo-

5 Dokładne dane bibliograficzne podaje Nowy Korbut - por. „Baworowski Wiktor (18261894)” 1968: 138, na którym opieram się również w przypadku kolejnych tytułów wymienianych w niniejszym tekście. 
rowski tłumaczył jeszcze Don Juana i zdaje się, że właśnie ten przekład, jak już zaznaczyłem, przysporzył mu jako tłumaczowi największe uznanie. Lecz i w tym wypadku nie ogłosił całego przekładu drukiem, z 16 pieśni w latach 1856-1882 ukazało się w czasopismach oraz jako osobne druki w sumie 10, i również tu cały przekład istnieje tylko w rękopisie. Trudno odpowiedzieć na pytanie, dlaczego Baworowski opublikował tak niewiele swoich przekładów. Wiktor Hahn przypuszcza, że na pewno nie było to spowodowane względami finansowymi - przypomnę, że Baworowski był człowiekiem bardzo bogatym, raczej były to „zbyt wielkie wymagania, stawiane sobie samemu” (Hahn 1946: 182).

Z obszerniejszych przekładów Baworowskiego w całości ukazał się zatem jedynie wspomniany Oberon. W wypadku większości przekładów Baworowskiego mamy do czynienia z drobnymi tekstami poetyckimi, jak ballady lub sonety, które czasem wydawał własnym nakładem, najczęściej jednak (w latach 1853-1889) publikował w rozmaitych gazetach lub czasopismach. Nie chciałbym się w tym miejscu wdawać w szczegóły bibliograficzne i odsyłam w tej sprawie jeszcze raz do Nowego Korbuta. Podaję tylko podstawowe informacje: były to tłumaczenia z niemieckiego (np. Johanna Wolfganga Goethego, Friedricha Schillera, Gottfrieda Augusta Bürgera lub Ludwiga Uhlanda), $\mathrm{z}$ angielskiego (jeszcze raz Byron) lub z francuskiego (Wiktora Hugo lub Jacques-Melchiora Villefranche’a). Tłumaczył także z łaciny - Horacjusza oraz znowu Adama Mickiewicza i jego odę do Napoleona III Na zdobycie Bomarsundu (Ad Napolionem III Caesarem Augustum Ode in Bomersundum captum), którą wydał jako osobny, czterostronicowy druk w Tarnopolu w 1863 roku.

Jak można scharakteryzować Wiktora z Baworowa - pod tym pseudonimem publikował swoje przekłady - jako tłumacza? Najważniejszym źródłem pozwalającym poznać jego poglądy o tłumaczeniu jest nieopublikowany tekst O tłumaczeniach, liczący nie mniej niż 56 stron, który zachował się w formie rękopisu ${ }^{6}$. Tekst ten jest nie tyle esejem w ścisłym sensie teoretycznym, ile ra-

\footnotetext{
${ }^{6}$ Istnieją dwie identyczne wersje tego tekstu, oprócz oryginału (Baworowski b. r./b) jeszcze druga (Baworowski b. r./c), oznaczona jako „kopja”. Nie wiadomo natomiast, czy Baworowski sam ją sporządził, różny charakter pisma sugeruje jednak, że raczej nie. Oba rękopisy znajdują się obecnie w Lwowskiej Narodowej Naukowej Bibliotece Ukrainy im. W. Stefanyka, do której podczas okupacji radzieckiej po wybuchu drugiej wojny światowej trafiła większość polskich kolekcji i księgozbiorów, w tym te z fundacji Baworowskiego. Do dziś zbiory Baworovianum znajdują się prawie w całości we Lwowie, szacuje się, że w ok. 98\%. Pozostałe rękopisy, starodruki i książki trafiły m.in. do Biblioteki Narodowej w Warszawie lub do Ossolineum we Wrocławiu (por. Chamera-Nowak 2008: 55). Na stronach internetowych Ossolineum są dostępne zdigitalizowane rę-
} 
czej refleksją o istocie tłumaczenia. Baworowski stara się poza tym dać w nim zarys historii polskiego przekładu literackiego i wymienia najlepsze jego zdaniem przekłady, począwszy od XVI wieku aż do czasów mu współczesnych. Jego zamiarem było przy tym pokazanie, jaką zasługę w rozwoju języka i piśmiennictwa polskiego - „ono na nich wzrosło i kształciło się” $(5)^{7}$ - mają właśnie dobre przekłady, które w jednym miejscu określa nawet jako „nieocenione dobrodziejstwa” (14). Ma to miejsce szczególnie w wypadku wybitnych pisarzy, którzy nie tylko przez swoje dzieła oryginalne, lecz także poprzez swoje tłumaczenia przyczynili się do rozwoju literatury polskiej. Odnośnie do np. wykonanego przez Mickiewicza tłumaczenia Zdań i uwag z Jakuba Boehme i innych ${ }^{8}$ pisze Baworowski: „Na równi z własnemi utworami, a pod względem bogactwa treści i klasyczności oddania, nawet w wyższej mierze od niejednego, zbogacił tłumacz tym zbiorkiem myśli luźnych piśmiennictwo” (36). Dlatego stawia w związku z tym nawet pytanie: „czy reszta naszych pisarzy narodowych, originalnych, nietłumaczów, zbogaciła i zbogaca w równym stopniu, piśmiennictwo polskie?” (40). Słowa te świadczą moim zdaniem o wyjątkowo wysokim znaczeniu, które Baworowski przypisuje przekładowi; zaznacza też, że najwięksi zagraniczni pisarze, jak Johann Gottfried Herder, Goethe, Schiller lub Lord Byron i François-René de Chateaubriand „nie mieli sobie za ujmę godności” (39), kiedy tłumaczyli z innych języków. Z polskich pisarzy Baworowski wymienia m.in. Adama Mickiewicza, Juliusza Słowackiego lub Antoniego Edwarda Odyńca i Kazimierza Brodzińskiego. W jednym miejscu życzy polskiemu piśmiennictwu nawet „mniej utworów oryginalnych choćby na tle narodowem, a więcej, choćby po kilka dobrych tłumaczeń każdego z wielkich pisarzy zagranicznych" (44).

Za tymi słowami Baworowskiego stoi jego przekonanie, że polski jest językiem wysoko rozwiniętym pod względem bogactwa wyrazu: „Posiadamy język”, pisze, kończąc swój wywód, „co oddaje lub mocen jest oddać wszystkie pomysły Greków, Rzymian, Włochów, Anglików i innych narodów” (44). Nie jest to jednak przekonanie powszechne, co pokazuje na przykładzie swojego nauczyciela Kamińskiego. Pobudką dla niego, twierdzi Baworowski, żeby tłumaczyć Schillera na język polski, było „czyjeś powiedzenie, że „ję-

kopisy z Biblioteki Baworowskich, z których korzystałem przy pisaniu tego artykułu, gdyż wśród nich znajduje się także wspomniany tekst Baworowskiego O tłumaczeniach.

7 Tekst Baworowskiego nie ma paginacji, w tekście powyżej podane strony (zwykłą cyfrą arabską) mają ułatwić odnalezienie zacytowanych fragmentów. Skorzystam przy tym ze wspomnianej drugiej wersji tekstu (Baworowskiego b. r./c), gdyż jest ona lepiej czytelna.

8 Pełny tytuł wydania np. z 2003 roku brzmi: Zdania i uwagi z dzieł Jakóba Boehme, Anioła Szlązaka i Saint Martina (oprac. Adama Mickiewicza). 
zyk polski nie jest żadną miarą w stanie oddać myśli niemieckiego pierwowzoru” (21). Do pozytywnych cech języka zalicza Baworowski „śpiewność, wielostronność, dosadność, męzkość, swobodę, pieszczotliwość, miękkość, powagę, głębokość, giętkość, delikatność, jasność [oraz] dar asymilacyi” (2), z których język polski wiele posiada. „Ale to dopiero instrument, i jeszcze trzeba ręki któraby na nim grała; i oto, otwiera się ta arena szermierzy nie zawsze fortunnych" (3).

W tym właśnie punkcie wyróżniają się zdaniem Baworowskiego wybitni tłumacze: „umiejętny tłumacz w zasobach własnego języka i pismiennictwa nie jedno dla przeciwstawienia pierwowzorowi znajdzie, gdy szukać umie" (35). Sąd ten ściśle wiąże się z tym, jak Baworowski pojmuje przekład i zadanie tłumacza:

Kto chce być godnym tego miana [tłumacza], musi oddać w swoim języku treść, ducha, ton, koloryt i formę pierwowzoru, lub, co do tej ostatniej, jeżeli nie zdoła lub nie powinien, niewolniczo jej się trzymać, winien zmodyfikować ją wedle wymogów swego języka, lub nawet zastąpić inną, byle wdzięczną i wykończoną (1-2).

Dobry przekład, który się marzy Baworowskiemu, cechuje się tym, że środkami własnego języka potrafi oddać to, co oryginał wyrażał pierwotnie. Nie chodzi tu ani o zachowanie i uwypuklenie obcości kulturowej, ani o jej maksymalne „udomowienie”: chodzi o tworzenie dzieła, które stoi na równi $\mathrm{z}$ oryginałem. Powstało ono wprawdzie na podstawie innego dzieła, nabywa jednak, dzięki silnemu ukorzenieniu w rodzimym języku i we własnej tradycji literackiej, prawa równe oryginałowi. Przekład w takim rozumieniu może oddalać się od oryginału. Dotyczy to, według Baworowskiego, w szczególności kwestii formy, którą uważa „za własność języka narodu” (31), co zapewne należy rozumieć w taki sposób, że właśnie dzięki swojej formie dzieło literackie jest najbardziej związane $\mathrm{z}$ tradycją danej kultury. Zwłaszcza najlepsi tłumacze postępowali jego zdaniem umiejętnie w tej kwestii:

Najwięksi mistrze jak Gete, Szyler, Delil, Dmochowski, Trembecki, Zabłocki, Sienkiewicz, Siemiński i inni dobierali odmiennej od oryginału formy w tłumaczeniach, najwłaściwszej językowi na jaki tłumaczyli niewymuszonej, wdzięcznej, nie obcej czytelnikowi dla którego pracowali, i w ten sposób ocalali przedmiot i treść samą (35).

Dlatego Baworowski tak wysoko ceni przekłady, o czym wspomniałem powyżej, i dlatego według niego mogą one też - o ile wykona je „umiejętny 
tłumacz" - przewyższać oryginał, jak to miało miejsce w wypadku Księcia Niezłomnego Pedra Calderóna de la Barca w przekładzie Słowackiego - „piękniejszy od oryginału" (28), tak samo jak Byronowski Giaur Mickiewicza. Ten właśnie przekład uważa Baworowski za „najlepszy z jakichkolwiek w naszem pismiennictwie, a zapewne w zagranicznych" (29), przyznając mu wysoką rangę również w twórczości samego Mickiewicza: „Wyłączając tak pomnikowe o wielkich rozmiarach utwory poetyckie jak Dziady i Pan Tadeusz, niewahałbym się Giaura polskiego na czele reszty, nawet wyżej od Wallenroda postawić” (29). I podsumowuje: „Mickiewicz nawet tłumacząc jest oryginalnym" (31).

Tłumaczenie, które dla Baworowskiego jest formą literackiej twórczości, może - rozumiane w charakterze rzemiosła poetyckiego - służyć jako przygotowanie do własnego pisarstwa:

Komu nie brak odpowiednego wykształcenia, kto włada językiem, obdarzony czuciem poetycznem, ma zapał i werwę - ten niech się zaraz niezrywa do współzawodnictwa $\mathrm{z}$ wieszczami, niech raczej obróci swe talenty na obeznanie nas z nimi, na uzupełnienie dotkliwych luk w pismiennictwie ojczystem (42).

Tłumaczenie może wręcz zastąpić własne pisarstwo, wielu jednak waha się przed takim krokiem ze względu na trudność tej pracy. Baworowski kontynuuje:

Jest to także zbawienną radą dla prawdziwych poetów, nie mogących jednak zawsze orlem skrzydłem szybować. Nie godzi się zalegać pola lub co smutniejsza, widzieć upadek własnego talentu w dziełach mniej godnych dawnej ustalonej sławy pisarza. Takiemu otwierają się jeszcze na oścież podwoje arcydzieł zagranicznych, nie mogąc być zawsze mistrzem=malarzem, niech będzie mistrzem=kopistą. Niech drudzy za niego, taki Szyler, Gete, Hugo, i tylu innych obmyślają poezję, on niech ją ubiera w szatę narodową i przywłaszcza językowi. Niech czyni, co tacy wielcy, przed nim już czynili. Nie będzie to zadaniem niegodnem jego talentu ani nawet jenjuszu; ale, mam raczej podejrzenie, że taki nie poczuwa się snać do możności sprostania tej walce atletów jedynie tylko ztąd że niedość swe siły ocenia, lub wytężać ich niechce. I zaiste, kunszt to nielada, i zwykle dość lekceważony (43).

Przedstawioną przez siebie koncepcję przekładu nazywa Baworowski „polską szkołą tłumaczów”, która wykształciła się w czasach wczesnego romantyzmu, przy czym dużą zasługę przyznaje właśnie Kamińskiemu, który jako „pierwszy lub omal pierwszy odstrychnąwszy się od szkoły pseudokla- 
sycznej”, utorował drogę romantykom, w tym Mickiewiczowi (21 i 24) ${ }^{9}$. Ta szkoła różni się od francuskiej i niemieckiej koncepcji przekładu: „Francuzi”, pisze Baworowski, „tłumaczą prozą lub parafrazują; Niemcy, mają za zadanie oddać i treść, i formę, »im Versmasse des Originals « ${ }^{10}$, jak się zwykli wyrażać” (4). I kontynuuje, że najbardziej artystycznie z zadania wywiązują się Polacy, dlatego przyznaje ich przekładom „wyższość nad innemi” (4 i 5), co właśnie chce, jak podkreśla, w swoim tekście pokazać (5). Istotą tej polskiej szkoły jest to, o czym już wcześniej wspomniałem: tworzenie w języku przekładu dzieła, które za pomocą środków językowych i stylistycznych właściwych temu językowi potrafi na nowo wyrazić oryginał, zachowując jednak jego charakter:

[...] to właśnie cechuje niedobrego tłumacza że pierwowzorom odbiera ich odrębność i w swoich przekładach czyni je do siebie podobnemi nadając im właśną cechę nijakości i bezbarwności, lub co gorsza, retoryzmu i napuszystości (3).

W taki sposób i w najlepszych wykonaniach, o których mowa była powyżej, przekład może stać się - rzec by można - drugim oryginałem.

Chciałbym teraz bliżej przyjrzeć się temu, jak Baworowski i jego tłumaczenia byli postrzegani przez współczesnych, a także prześledzić, na ile udało mu się w jego własnych przekładach zrealizować założenia, które sformułował w powyżej opisanym tekście $O$ tłumaczeniach ${ }^{11}$.

Przekładom Baworowskiego niejednokrotnie przyznawano, że w szczególny sposób urozmaicają literaturę polską. Tak np. lwowski germanista i jego bliski przyjaciel Albert Zipper pisze, że „wszystkie tłómaczenia Wiktora z Baworowa [są] prawdziwą ozdobą i wzbogaceniem zasobu piśmiennictwa naszego” (Zipper 1887: 4). Także Stanisław Tarnowski, krytyk literacki i późniejszy rektor Uniwersytetu Jagiellońskiego, podkreśla w krakowskim „Czasie” m.in.

9 Jako dowód Baworowski podaje dwuwiersz: „Izba wre, huczy i kipi, i pryska, // I szumowiny aż pod niebo ciska” z Ustępu III części Dziadów, który jego zdaniem Mickiewicz zapożyczył („żywem wzięte i zastosowane, 24) z tłumaczenia Kamińskiego Schillerowskiej ballady Nurek, gdzie można przeczytać: „I wre, i kipi, i huczy, i pryska// Właśnie jak woda, gdy się z ogniem zetrze” (Schiller 1954: 22). Również podczas swojej wizyty u Mickiewicza w 1853 roku powraca Baworowski do tego tłumaczenia Kamińskiego (por. Baworowski 1856: 42/334).

${ }^{10}$ W oryginale po niemiecku, czyli: „W metrum oryginału”.

11 Opieram się przy tym po pierwsze na wybranych recenzjach jego przekładów z ówczesnej prasy polskiej, które - co z dzisiejszej perspektywy można z pewną zazdrością stwierdzić - są nie tylko liczne, lecz i w odniesieniu do spraw przekładu bardzo szczegółowe. Po drugie uwzględniam portrety Baworowskiego, w których przedstawiony jest też na kanwie swojej pracy przekładowej, w pierwszej kolejności chodzi tu o liczne nekrologi, które się pojawiły po jego samobójczej śmierci w 1894 roku. 
ten aspekt a propos wydanego przez Baworowskiego w 1881 roku przekładu Don Juana Byrona (pieśni V-X). „Przekłady obcych poetów są nietylko ozdobą, ale konieczną potrzebą każdej literatury" - pisze, konkludując, że i w tym wypadku „nasza literatura może się pochwalić [tym] niezaprzeczonem zbogaceniem" (Tarnowski 1883: 180/1 oraz 184/2).

Najważniejszym kryterium dobrego przekładu jest dla Baworowskiego kwestia, czy tłumaczowi udało się „oddać w swoim języku treść, ducha, ton, koloryt i formę pierwowzoru” (Baworowski b. r./c: 1-2). I w tym punkcie znalazł aprobatę w odniesieniu do swoich własnych przekładów, i to ze strony nie byle kogo, lecz samego Henryka Sienkiewicza, który przeczytawszy Don Juana w przekładzie, pisze do niego w liście z 1889 roku:

Pan potrafiłeś przetłumaczyć na język polski nie tylko słowa, ale i piękność Don Juana - a wobec tej ogromnej i kapitalnej rzeczy, jakieś nieregularności oktawy, zresztą rzadkie, są drobnostką, do której mógłby się chyba przyczepić jakiś suchy pedant biegły w liczeniu zgłosek, ale niezdolny odczuć duszę utworu. [Liczne fragmenty] robią po prostu wrażenie nie przekładu, ale oryginalnego poematu. [...] Otóż ta dusza oryginalna, bajronowska, siedzi w pańskich oktawach. [...] Co to za swoboda, co za giętkość języka w ogóle, jak się to wszystko wije po bajronowsku, jak świeci niby wąż kolorowy. [...] Powtarzam, że nie jestem i nie będę nigdy pedantem szukałem duszy i piękności, a te znalazłem, jak również i świetną, bogatą, barwną, aż do podziwu formę... (Sienkiewicz 1951: 17-18).

Już kilka lat wcześniej, w 1863 roku, po wydaniu pierwszej pieśni Don Juana, nieznany recenzent „Czasu” pisze pod podobnym wrażeniem, że „umiał tłómacz szczęśliwie dykcyę zastósować do ducha naszego języka, i niekiedy obrazom i porównaniom dać pewien pokost polski, co wszystko odejmuje dziełu jego pochodzenie obce, a robi je prawdziwie przyswojonem” („Don Żuan Lorda Bajrona” 1863: 2).

Ale wróćmy do formy, o której wspomina Sienkiewicz i do której tylko „suchy pedant” mógłby się przyczepić. Według Baworowskiego tłumacz nie powinien „niewolniczo jej się [formy] trzymać”, lecz „zmodyfikować ją wedle wymogów swego języka, lub nawet zastąpić inną, byle wdzięczną i wykończoną" (Baworowski b. r./c: 2). Baworowski zrezygnował w przekładzie Don Juana - mimo powyżej zacytowanej uwagi Sienkiewicza - z oryginalnej formy oktawy i zastąpił ją - zgodnie ze swoim postulatem - skomplikowanym schematem rymowym (aba bab cc). Z tego lekki zarzut robi mu np. Feliks Jezierski, sam będący tłumaczem Byrona i autorem pierwszego pełnego polskiego przekładu Fausta Goethego, w „Bibliotece Warszawskiej”. Ale, jak pisze Je- 
zierski, „o ile korzystnem byłoby dla nas, gdyby tłómacz zachował był tę ramę [czyli oktawę - to jednak] w każdym razie milej jest posiadać Don Żuana w ścisłem odbiciu, aniżeli w oktawach, ale ze zmienionemi rysami" (Jezierski 1879: 477-478). Nieco krytyczniej wyraża się Tarnowski, który nie chce „zataić, że wolelibyśmy widzieć oktawę prawdziwą, niż ten jej pozór” i który sąd ten swój podpiera argumentem, że oktawa ma owocną tradycję w literaturze polskiej od XVI wieku, zwłaszcza po Słowackim (Tarnowski 1883: 180/2). Trudno jednak stwierdzić, czy Sienkiewicz odnosił się w swoim liście do Baworowskiego bezpośrednio do krytyk Jezierskiego lub Tarnowskiego.

Kilka razy podkreślał Baworowski swoje przekonanie o bogactwie języka polskiego, dzięki któremu „umiejętny tłumacz w [jego] zasobach” znajdzie wszystko, co mu do dobrego przekładu potrzebne (por. Baworowski b. r./c: 35). Nie chcąc - ze względu na ograniczone miejsce - zbytnio rozwijać tego wątku, podkreślam tylko, że w wielu omówieniach przekładów Baworowskiego właśnie jego język jest uważany za największy ich atut. Już w przypadku Oberona pisze Stanisław Piłat, sam tłumacz, na łamach lwowskiego „Dziennika Literackiego", że „Z prawdziwą uciechą witamy tłumaczenie, w którym widać język ojczysty czysty, płynny, jasny, wiersz gładki, miły, potoczysty i w ogólności przypominający klasyczny nastrój lutni wieszcza Zofijówki” (Pilat 1853: 86). Również dla Jezierskiego - teraz w odniesieniu do Don Juana -

język naszego tłómacza jest czysto-polski w całem znaczeniu tego wyrazu. [Wiele fragmentów może świadczyć o tym, że] naszemu pracownikowi chodziło o polskość przekładu. Również posługuje się rozległym repertoarem dźwięków polskich [... oraz legionami] słów, o których istnieniu jakoby już nie wiedziano (Jezierski 1879: 475-476).

Zauważa to w końcu jeden z największych entuzjastów przekładów Baworowskiego $^{12}$ - Henryk Sienkiewicz, w już zacytowanym liście dotyczącym Don Juana: „Ja się kocham w polskim języku i dlatego, co mnie jeszcze zachwyca w tym przekładzie, to ta copia verborum" (Sienkiewicz 1951: 17). Podobna opinia pada również z ust uznanego autorytetu literackiego, mianowicie samego Adama Mickiewicza, któremu podczas odwiedzin Bawo-

${ }^{12}$ O pozytywnej krytyce Sienkiewicza pod adresem przekładów Baworowskiego pisze Hahn: „Ile w tej ocenie Sienkiewicza głębokiego odczucia wartości tłumaczenia, a jakie subtelne, świadczące o niezwykłym wżyciu się w intencje tłumacza, te słowa, przepojone prawdziwą radością, że pojawił się przekład tak piękny, prawdziwa ozdoba naszej literatury. Wśród licznych ocen literackich, jakie wyszły z pod pióra Sienkiewicza, może ta jest jedną z najpiękniejszych" (Hahn 1946: 182). 
rowski przeczytał fragmenty tłumaczenia Oberona. „Pochwalił więc bardzo”, relacjonuje Baworowski reakcję Mickiewicza, „znajomość języka w mojem tłumaczeniu, rzekł, że jest doskonałe, gruntowne, przewyższające oryginał" (Baworowski 1856: 42/334). I właśnie myśl, że dobre tłumaczenie może przewyższyć nawet oryginał, odgrywa kluczową rolę w koncepcji przekładu Baworowskiego.

Przytoczyłem zaledwie kilka z wielu opinii o przekładach Baworowskiego, które były naprawdę obszernie opisywane i analizowane przez ówczesną krytykę literacką. Następnym krokiem w analizie jego twórczości tłumaczeniowej mogłaby być próba odniesienia tych kluczowych aspektów jego poglądów na temat przekładu do konkretnych rozwiązań, które zastosował w poszczególnych swoich przekładach. Interesujące wydaje się również pytanie, na ile Baworowski i jego kariera jako tłumacza są typowe dla XIX wieku - kwestię tę można by prześledzić, porównując go z innymi tłumaczami tego okresu. Na pewno jednak jego postawa i dzieło mieszczą się w duchu Polski porozbiorowej, XIX-wiecznej, w której dbanie o własną kulturę, w tym język, było przez szerokie warstwy społeczne uznawane za zadanie nader ważne. Jak pokazałem, przekład dla Baworowskiego to w dużej mierze tworzenie, oczywiście na podstawie oryginału, autonomicznego dzieła za pomocą środków i tradycji literackich własnego języka. W tym punkcie praca tłumaczeniowa styka się z jego aktywnością kolekcjonerską, gdyż i w tej drugiej na pierwszy plan wysuwa się troska o polską kulturę oraz o ratowanie dóbr, które świadczą o jej bogactwie. Baworowski wpisuje się tutaj w tradycję bardzo popularną wśród XIX-wiecznych elit galicyjskich i polskich. Patriotyczny wymiar zarówno przekładowej, jak i kolekcjonerskiej działalności Baworowskiego widział m.in. Kornel Ujejski, któremu imponowała ta „praca dla narodu”. Jak pisze w liście do niego: „Dusza tego [...] co ofiarą całego majątku sięga w narodową przyszłość, już posiada błogosławione jasnowidzenie" (cyt. za Nadolski 1934: 141). Zgodnie z takim rozumieniem zadania tłumacza, w pracy przekładowej nie chodzi o to, by na bieżąco zapoznawać własną kulturę z najnowszymi osiągnięciami obcych literatur - kiedy bowiem Baworowski tłumaczył Wielanda lub Byrona, oni dawno już zniknęli z głównego nurtu obiegu czytelniczego ${ }^{13}$.

${ }^{13}$ Znamienna jest pod tym względem anegdota o staraniach Baworowskiego o założenie w Krakowie w latach 70. XIX wieku Towarzystwa Bajronistów, które miał zamiar hojnie wesprzeć finansowo. Towarzystwo zebrało się jednak tylko raz, ponieważ jego przewodniczący, galicyjski pisarz Łucjan Siemieński, odczytawszy jedną z pieśni Don Juana, złożył prezesostwo słowami: „niech przepadną miliony - mam już dość Byrona i bajronistów (zob. Dębicki 1906: 233). 


\section{Literatura}

Balcerzan, E., Rajewska, E. (red.), 2007, Pisarze polscy o sztuce przekładu 1440-2005. Antologia, Poznań.

Barycz, H., 1963, Wśród gawędziarzy, pamiętnikarzy i uczonych galicyjskich. Studia i sylwety z życia umysłowego Galicji XIX w., Kraków.

Baworowski, W., 1856, Odwiedziny u Mickiewicza, „Nowiny”, nr 41, s. 326-327, nr 42, s. 334 i nr 43, s. 341.

Baworowski, W., 1888, Notatka o liście A. Mickiewicza do J. N. Kamińskiego, „Pamiętnik Towarzystwa Literackiego imienia Adama Mickiewicza”, r. 2, s. $153-154$.

Baworowski, W., b. r./a, Notatka o Wiktorze Baworowskim, rękopis Biblioteki Jagiellońskiej sygn. 6161 III (http://jbc.bj.uj.edu.pl/dlibra/docmetadata?id=284462\&from=\&dirids= 1 \&ver_id=\&lp=9\&QI=; dostęp: 20 sierpnia 2017 r.).

Baworowski, W., b. r./b, O tłumaczeniach, rękopis Lwowskiej Naukowej Biblioteki im. W. Stefanyka Narodowej Akademii Nauk Ukrainy zesp. 4, sygn. 1537 (http:// http://bazy.oss.wroc.pl/kzc/view_fond.php; dostęp: 30 czerwca 2016 r.).

Baworowski, W., b. r./c, O tłumaczeniach - kopja, rękopis Lwowskiej Naukowej Biblioteki im. W. Stefanyka Narodowej Akademii Nauk Ukrainy zesp. 4, sygn. 1535 (http:// http://bazy.oss.wroc.pl/kzc/view_fond.php; dostęp: 30 czerwca 2016 r.).

„Baworowski Wiktor (1826-1894)”, 1968, [w:] Bibliografia Literatury Polskiej Nowy Korbut, t. 7: Romantyzm, E. Aleksandrowska i in. (red.), Warszawa, s. 138-139.

„Baworowski hr. Wiktor”, 1989, [w:] Polski Słownik Biograficzny, t. 1, W. Konopczyński i in. (red.), Wrocław i in., s. 368-370.

Byron, G. G., 1863, Don Żuan Lorda Bajrona. Pieśń pierwsza, przeł. przez Wiktora z Baworowa, Tarnopol.

Byron, G. G., 1879, Don Żuan. Pieśń druga, trzecia i czwarta. Opowiadanie o haidzie, przeł. Wiktor z Baworowa, Tarnopol.

Chamera-Nowak, A., 2008, Zarys problematyki dotyczacej biblioteki fundacji Wiktora hr. Baworowskiego, „Czasopismo Zakładu Narodowego imienia Ossolińskich”, nr 18/19, s. 55-64.

Dębicki, L., 1906, Portrety i sylwetki $z$ dziewiętnastego stulecia. Serya II, Kraków.

Don Żuan Lorda Bajrona. Pieśń pierwsza przełożona przez Wiktora z Baworowa, 1863, „Czas”, nr 208, s. 1-2. 
Dybiec, J., 2004, Nie tylko szablą. Nauka i kultura polska w walce o utrzymanie tożsamości narodowej 1795-1918, Kraków.

Hahn, W., 1946, Henryk Sienkiewicz i Wiktor Baworowski, „Nauka i Sztuka, nr 7-8, s. 180-182.

Jezierski, F., 1879, „Don Żuan Bajrona”, [w:] Biblioteka Warszawska. Pismo poświęcone naukom, sztukom i przemysłowi, t. 2, s. 473-479.

Kraszewski, J. I., 1877, Wiktor hr. Baworowski, „Tygodnik Ilustrowany”, nr 68, s. $225-227$.

Lasocka, B., 1972, Jan Nepomucen Kamiński, Warszawa.

Nadolski, B., 1934, Stosunki Ujejskiego i Sienkiewicza z Baworowskim, „Ruch Literacki”, nr 5, s. 140-142.

Piłat, S., 1853, Nowe dzieło, „Dziennik Literacki”, nr 11, s. 86-87.

Sadkowski, W., 2013, Odpowiednie dać słowu słowo, Toruń.

Schiller, F., 1954, Ballady. Wybór, Warszawa.

Sienkiewicz, H., 1951, Dzieła, t. LV, J. Krzyżanowski (red.), Warszawa.

Tarnowski, S., 1883, „Don Juan” Byrona w polskich tłumaczeniach, „Czas”, nr 180, s. 1-2, nr 182, s. 1 oraz nr 184, s. 1-2.

Wiktor hr. Baworowski, 1894b, „Kraj”, nr 48, s. 16.

Zipper, A., 1887, Notatki literacko-artystyczne, „Gazeta Lwowska”, nr 229, s. 4.

\section{Count Wiktor Baworowski: bibliophile and translator}

Summary

Count Wiktor Baworowski (1826-1894) is known as a Galician bibliophile and founder of the library named after him. This article aims at recalling his translation activity as he translated into Polish such important $19^{\text {th }}$ century as Ch. Wieland, G. Byron or V. Hugo. After a brief presentation of his biography as well as linguistic and literary socialization, his text O ttumaczeniach (About translations) is discussed in detail. It is an extensive reflection on the significance and history of literary translation in Poland. The final part of the article demonstrates the reception of Baworowski's translations by the contemporary literary criticism and attempts at answering the question as to the extent, to which his activity as a translator and as a book collector is rooted in and derived from convergent intentions.

Keywords: Wiktor Baworowski, literary translation in the $19^{\text {th }}$ century, history of translation (Poland), translator (biography) 
